Please do not remove this page

RMIT

UNIVERSITY

\title{
Upstream transport corridor inefficiencies and the implications for port performance: A case analysis of Mombasa Port and the Northern Corridor
}

Gekara, Victor; Chhetri, Prem

https://researchrepository.rmit.edu.au/esploro/outputs/9921859174001341/filesAndLinks?institution=61RMIT_INST\&index=null

Gekara, V., \& Chhetri, P. (2013). Upstream transport corridor inefficiencies and the implications for port performance: A case analysis of Mombasa Port and the Northern Corridor. Maritime Policy and Management, 40(6), 559-573. https://doi.org/10.1080/03088839.2013.776716

Document Version: Accepted Manuscript

Published Version: https://doi.org/10.1080/03088839.2013.776716

Repository homepage: https://researchrepository.rmit.edu.au

(C) 2013 Taylor \& Francis

Downloaded On 2023/04/27 00:27:02 +1000

Please do not remove this page 
Thank you for downloading this document from the RMIT Research Repository.

The RMIT Research Repository is an open access database showcasing the research outputs of RMIT University researchers.

RMIT Research Repository: http://researchbank.rmit.edu.au/

\section{Citation:}

Gekara, V and Chhetri, P 2013, 'Upstream transport corridor inefficiencies and the implications for port performance: A case analysis of Mombasa Port and the Northern Corridor', Maritime Policy and Management, pp. 1-15.

See this record in the RMIT Research Repository at:

http://researchbank.rmit.edu.au/view/rmit:21008

Version: Accepted Manuscript

Copyright Statement: (c) 2013 Taylor \& Francis

Link to Published Version:

http://dx.doi.org/10.1080/03088839.2013.776716 


\title{
Upstream transport corridor inefficiencies and the implications for port performance: a case analysis of Mombasa Port and the northern corridor
}

\section{Dr. Victor Oyaro Gekara* and Prof. Prem Chhetri*}

\section{School of Business, IT and Logistics and Centre for Sustainable Organisations and Work, RMIT}

\author{
$\underline{\text { University - Melbourne }}$
}

\begin{abstract}
The role of efficient ports in the socio-economic prosperity of national and regional economies cannot be over-stated. However, their ability to effectively deliver on this role is easily undermined by circumstances in the wider socio-economic context, particularly poor hinterland connectivity. In order to enhance international trade connectivity, many advanced and advancing economies continue to invest significant resources in developing efficient ports and hinterland transport networks. The situation is different in many parts of the developing world, particularly Africa where poor economic connectivity and inefficient gateway ports result in prohibitively high transportation costs. Focusing on the Northern trade and transport Corridor in the East and Southern Africa (ESA) region, this paper examines how poor hinterland connectivity undermines the performance of Mombasa Port. It concludes that, although the port's management has in recent years invested significantly in performance-enhancing initiatives, their success is limited by a constricted economic environment that is characterised by poor hinterland connectivity and chronic logistics bottlenecks along the arterial corridor.
\end{abstract}

Coverage: Mombasa port; port performance; logistics efficiency; hinterland connectivity; transport bottlenecks; transport corridors

\section{Introduction}

In this paper, we examine the question of logistics accessibility in Africa with specific reference to the East African region. Using the Northern Transport Corridor as a case-study, we examine how hinterland logistics bottlenecks affect the performance of the key East African gateway port. The Northern Corridor links the port to its hinterland, which includes Uganda, Northern Tanzania, Rwanda, Burundi, Eastern Democratic Republic of Congo (DRC), South Sudan and Ethiopia.

We argue that successful and efficient gateway ports are often those that are effectively connected to their economic hinterlands by adequate and effective transport corridors (Limão and Venables 2001). Ports in the least developed and developing economies, however, are often constrained by insufficient hinterland logistics connectivity (Limão and Venables 2001). Inadequate logistics infrastructure also 
means that the cost of production and distribution remains prohibitive, leading to low levels of trade and lack of competitiveness on the international market. Consequently, these countries continue to experience low economic growth rates (Amjadi and Yates 1995).

The African continent is a typical example of logistics under-capacity and inefficiency, prohibitive production and distribution costs, and economic under-development (Amjadi and Yates 1995; AfDB 2010). A number of major factors contribute to this situation. First, the entire continent is serviced by only 21 key ports, most of which are inefficient, under-funded and of low infrastructure capacity. In the main, they are unable to handle large freight volumes and large vessels. Of these African ports, only three rank in the top 100 world container ports compared to Europe, for example, which has 21 major container ports, half of which, according to the Containerisation International Yearbook 2012, rank in the world's top 100. Second, the continent is home to 16 landlocked countries (the largest number of any other continent), which depend entirely on transit countries for their international trade. This further reduces the extent of integration into global supply chains. Limão and Venables (2001) show that a land-locked country's transport costs can be up to 55 per cent higher than those of a comparable coastal country. They further find that, the combination of being land-locked, having poor transportation infrastructure and relying on transit countries with similarly poor transportation infrastructure, significantly undermines trade. This is the situation facing all of the African landlocked countries, making transportation inefficient and costly. Third, inland connectivity is characterised by a low capacity road network that is largely limited to urban centres (AfDB 2010), an out-dated and fragmented rail infrastructure, and a non-existent inland waterway transport system (despite the existence of many navigable rivers and lakes) (Ntamutumba 2010). For these reasons, the overall cost of transportation and, by extension, doing business in African countries is much higher than other developing regions like Latin America and Asia (Limão and Venables 2001; Amjadi and Yates 1995). To this end Limão and Venables (2001) conclude that the high costs of transportation in Sub-Saharan Africa accounts for much of the region's poor economic performance.

In order to enhance logistics efficiencies and boost international trade on the continent, governments since the mid-1990s have embarked on formulating strategic reforms, particularly in the ports and inland transportation, in collaboration with lending organisations like the World Bank and the African Development Bank. Some of these reforms have involved establishing public-private partnerships in the development and management of various aspects of the logistics chain, including ports, roads, railways and waterways (UNCTAD 2003; Tongzon and Heng 2005). Furthermore, there is a growing view that enhanced inland connectivity, which is capable of providing land-locked countries with effective access to ports, requires the adoption of a holistic trans-border management approach (Ntamutumba 2010). Thus far, a corridor management approach has been embraced for the development, regulation and management of trade and transportation channels between key regional gateway ports and their hinterlands. Under this approach, the development and management of hinterland transportation channels is charged to a regional body (e.g. The Transit Transport Co-Ordination Authority of the Northern Corridor (TTCANC)) that is representative of all the countries involved. It is a strategy that is 
meant to facilitate greater harmonisation of regional transportation policies, coordinate cross-border investment in infrastructure, and keep open channels for landlocked countries (AfDB 2010; Ntamutumba 2010). However, the effectiveness of this approach in encouraging inter-government collaboration, improving port-hinterland connectivity, and facilitating a seamless flow of freight along the transportation channels is yet to be examined and evaluated.

For now, this paper's primary objective is to examine the negative impact of poor hinterland connectivity on the performance of Mombasa port. In order to do this, we examine the current performance situation at the port and identify the key issues and highlight some of the performance improvement initiatives recently implemented at the port and assess their effectiveness. We also discuss hinterland connectivity limitations and upstream logistics bottlenecks and investigate how the situation undermines the achievement of enhanced port performance. Little research has been conducted in this area and little is written about challenges for ports in the context of developing countries, particularly those in Africa. The paper contributes to academic and policy discussions on efficient transport corridors and effective regional gateway ports in Africa's developing countries. Though the analysis is limited to the East and Southern Africa region (EAS), and specifically the Northern Corridor, the situation closely mirrors the dominant logistics environments across the continent.

Our analysis focuses on the port's performance challenges and demonstrates how upstream corridor inefficiencies have consistently undermined its quest for greater effectiveness as the region's main trade gateway. The analysis is based on the premise that port performance is assessed within a broad operations environment, usually comprising an intricately interconnected system of divergent social, political and economic institutions. Unless their functions are effectively managed and coordinated, they often become sources of inefficiency to port operations and, in turn, create logistics bottlenecks. In a recent African Development Banks's report (AfDB 2010, 207), this point is emphasised:

a port is only as good, and its development only as viable, as the transport networks linking the ports to centres of production and consumption.

In addition to localised institutional and management problems, we propose that a large part of the failure of the port to deliver in its role as trade and economic catalyst is attributable to logistics limitations and inefficiencies upstream, which have left it struggling in a constrained environment, and rendered it economically vulnerable.

The analysis is developed in six broad sections. Following this introduction is section two, a brief description of the study on which the analysis is based. Section three presents an overview of the Port and its performance issues, highlighting recent initiatives by the port authority to enhance performance. This is followed by section four, which examines the hinterland connectivity and logistics situation. Section five discusses the impact of upstream logistics bottlenecks on port performance, and section six presents a brief concluding assessment. 


\section{The study}

The data informing this paper is drawn from the initial stages of an on-going qualitative study focusing on port operations performance, hinterland connectivity and logistics efficiency in the East and Central African region (ESA). The wider study focuses on key ports in the Djibouti-Durban range and their inland connectivity. Specifically, the research involves in-depth interviews conducted with various participants from Mombasa port and a wide selection of stakeholders within the broad maritime and logistics sector, including ocean and overland carriers, freight forwarders, importers, exporters and unions, as well as relevant government agencies. At this stage, initial interviews were conducted in January 2011 with 10 officials drawn from the Kenya Ports Authority (KPA), Kenya Maritime Association (KMA), Kenya Shippers Association (KSA), the Port Management Association of East and Southern Africa (PMAESA) and overland carriers based in Mombasa. Other sources of data include port performance statistics drawn from official port annual reports, World Bank, and UNCTAD statistics.

\section{Mombasa port and its hinterland}

\section{An overview}

Mombasa port is the only deep-sea port in Kenya and the main trade gateway to an extensive economic hinterland in the Eastern Africa region stretching across Uganda, Rwanda and Burundi to Eastern DRC and South Sudan. It also serves the regions of northern Tanzania and Ethiopia. The main arterial cargo highway runs from the Port city of Mombasa through Nairobi, Kampala to Kisangani in Eastern DRC. Distributaries branch off to Mwanza, Addis Ababa, Juba, Bujumbura and Kigali. Five of the countries in the region are land-locked and rely entirely on the port as their sole trade gateway. As such, it remains the most important seaport on the east coast of Africa.

The port consists of 16 deep-water berths, a dedicated container terminal, two bulk terminals (cereals and cement), two oil terminals and a passenger terminal. Although some reference is made to other cargo, the discussion here predominantly focuses on container freight operations for two reasons: first, their operations are relatively complex; and second, container operations have experienced fast growth relative to others. In the Containerisation International Yearbook 2012, Mombasa port is ranked $5^{\text {th }}$ in Africa (with 696,000 TEU) after Durban, Tangier, Les Palmas de Gran Canaria and Cape Town. The report also indicates that, within five years from 2006, the port achieved more than $130 \%$ TEU increase.

Despite the extensive hinterland the port commands and recent increases in throughput, its overall performance remains significantly below international standards; for example, it handles under a quarter of the container volumes handled at Durban port, and only about two per cent of what goes through Singapore and Hong Kong (BITRE 2009). Furthermore, it is estimated that, as a result of issues related to inefficiency, freight costs represent $35-40 \%$ of import values to the region as compared to $8 \%$ in European ports (AfDB 2010; Ntamutumba 2010). 


\section{Port productivity and performance}

The United Nations Conference on Trade and Development (UNCTAD) has developed a set of indicators for assessing port performance, which are broadly designated into financial and operational performance categories. The former relates to the costs and revenue of port operations, wherein a port is considered to be efficient and competitive if revenue outweighs the costs. The latter, which is of more central and direct concern to the port management, and of great interest to port clients, includes key indicators such as vessel arrival rates, waiting and turnaround time, and berth occupancy and cargo dwell time. These indicators are developed to represent operational performance, which could then be measured and compared against industry standards or benchmarks. Although we take all these factors into consideration in our analysis of the situation at the Mombasa port, we base our assessment mainly on vessel turnaround, which is influenced by arrival rates, waiting times and cargo off-take. The average turnaround rate at any given port is often a good indicator of how efficient the port is overall, including its shipping operations, cargo loading and unloading, and onward clearance (BITRE 2009). It further indicates the condition and efficiency of port equipment, its information management systems, and its workforce.

In the 1980s and 1990s, the port was plagued by many problems which saw its growth stagnate. From an institutional perspective, the situation was brought about by a combination of issues including inadequate and ageing facilities, poor hinterland transport infrastructure, and inefficient cargo clearance procedures that led to slow vessel turnaround and cargo off-take, and chronic vessel congestion. Cargo security was also a major problem, with rampant cargo loss and damage. From a management perspective, port operations struggled under stifling bureaucracy, political interference, and rampant corruption among port officials, low employee morale and financial mismanagement (AfDB 2010; Ntamutumba 2010). These problems persist to some extent, but of greater concern is that the port currently suffers from basic capacity and operations restrictions. According to interviews with key stakeholders, the problem is associated with a growing emphasis on productivity and the management's focus on increasing throughput with little attention to the enhancement of internal operations capacity. According to one stakeholder, the port has "until recently preoccupied itself more with image and marketing... cosmetic changes", as opposed to "seriously tackling performance and capacity issues" (Kenya Shippers council official, 2011). For example, a container terminal that was designed to 250, 000 TEUs is now expected to handle close to 700,000 TEUs. This has led to persistent port congestion and long vessel waiting times (figure 1). 
Figure 1: Trends in average ship waiting time (net days) in the Port of Mombasa

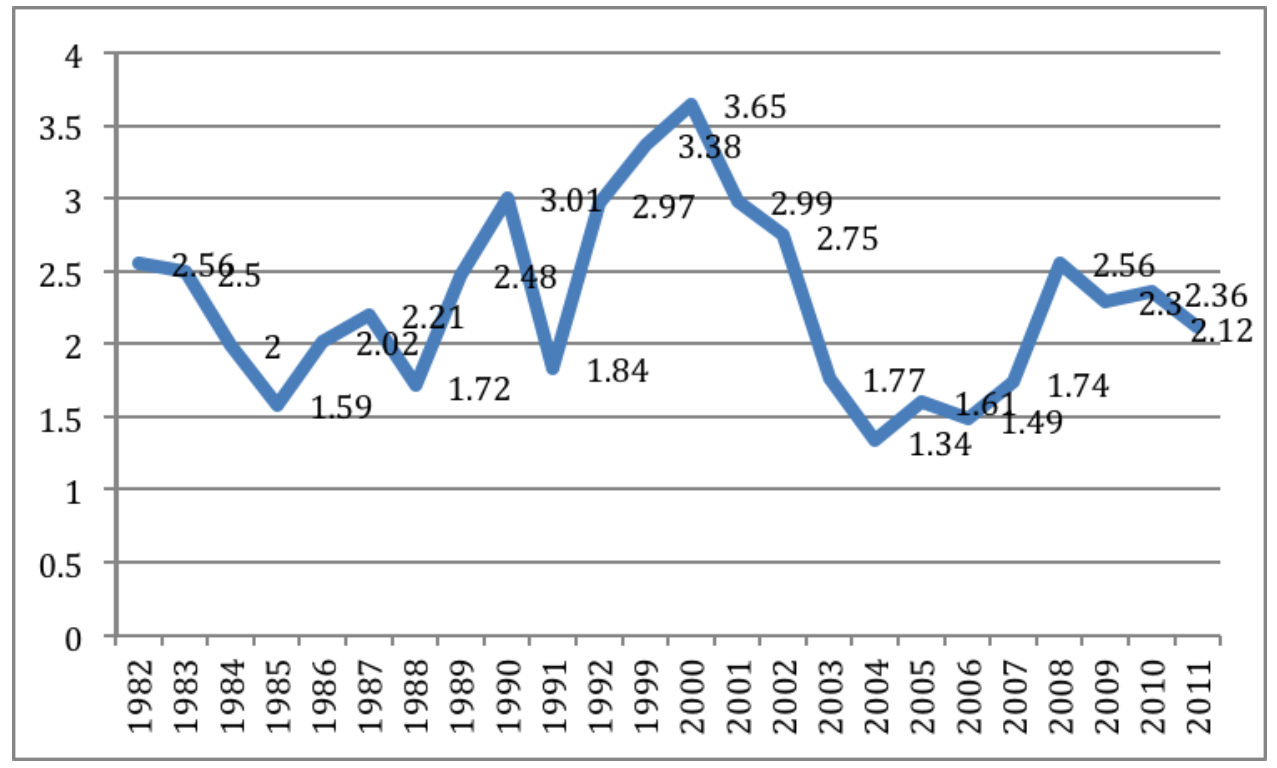

Source: KPA annual statistics, various years

From the statistics available, average waiting time per ship is predominantly high, at 2 days per ship, but this figure is also characterised by large fluctuations. This indicates an inefficient cargo handling process, as well as unstable and inconsistent performance over the years. According to port officials, fluctuations in waiting times are influenced by erratic rains, which cause damage to the inland roads. The sharp rise in waiting times between 1990 and 2000, for example, was partly because of damage to the main Mombasa-Nairobi road, largely because the road was under reconstruction and only part accessible for the most part. Because there is no alternative route, such situations often result in heavy traffic congestion and a pile-up of cargo at the port because of slow cargo off-take. Such long waiting times have implications for vessel turnaround, which has also been consistently high at about 4.8 days per ship on average. Considering that turnaround times in the world's best performing ports have reduced to less than 1.3 days, with global averages dropping drastically (see table 1), Mombasa Port's current turnaround rates are not a good indication of efficiency.

The situation is apparently much worse in peak seasons like Christmas, which also explains the large fluctuations in vessel waiting (figure 1) and turnaround (figure 1) times. In a performance analysis by the Daily Nation newspaper on 10, January, 2012, it was established that, in the few months leading to December 2011, ships were waiting 10-15 days for berth allocation, cargo dwell-time was 6 days (up from 5), and that it took 30 days to process a container through the port and transport it to Kigali in 
Rwanda (up from 24). During this period, vessel turnaround time rose to $14-20$ days. The cumulative impact of underperformance is maintained, with upstream bottlenecks leading to container congestion at the Inland Container Freight Stations (ICFSs) ${ }^{1}$ and the port. This further means that ships have to wait longer for berth allocation and, consequently, experience long turnaround times. All key logistics stakeholders are affected with these delays and rising costs.

This is a far cry from the cargo operation rates in most of the best performing ports in the world, as illustrated by a recent study of top container ports (BITRE 2009), where the median turnaround time (as per 2009) was 1.1 days. The shortest average turnaround time in the selection was at Port Klang in Malaysia at 11 hours, and the longest was Durban at 3 days (table 1).

Table 1: Port Turnaround for Major Selected Ports 2009

\begin{tabular}{|l|l|l|l|l|l|}
\hline Port & \multicolumn{2}{|l|}{ Duration } & Port & \multicolumn{2}{l|}{ Duration } \\
\hline & Hours & Days & & Hours & Days \\
\hline Singapore & 26 & 1.1 & Le Havre & 18 & 0.8 \\
\hline Hong Kong & 23 & 1.0 & Melbourne & 31 & 1.3 \\
\hline Shanghai & 19 & 0.8 & East Port Said Port & 18 & 0.8 \\
\hline Busan & 13 & 0.5 & Sydney Ports & 29 & 1.3 \\
\hline Rotterdam & 40 & 1.7 & Karachi & 19 & 0.8 \\
\hline Hamburg & 25 & 1.0 & Manzanillo & 26 & 1.1 \\
\hline Los Angeles & 61 & 2.5 & Puerto de Buenos Aires & 36 & 1.5 \\
\hline Long Beach & 24 & 1.0 & Port of Brisbane & 34 & 1.4 \\
\hline Port Klang & 11 & 0.5 & Izmir & 52 & 2.2 \\
\hline New York/New Jersey & 22 & 0.9 & Gothenburg & 30 & 1.3 \\
\hline Laem Chabang & 12 & 0.5 & Channai (Madras) & 41 & 1.7 \\
\hline Tokyo & 22 & 0.9 & Tauranga & 31 & 1.3 \\
\hline Santos & 37 & 1.5 & Auckland & 37 & 1.5 \\
\hline Vancouver & 49 & 2.0 & Fremantle & 27 & 1.1 \\
\hline Durban & 72 & 3.0 & Adelaide & 22 & 0.9 \\
\hline
\end{tabular}

Source: Adapted from BITRE [10:14]

The implications of such slow vessel turnaround times are numerous and far-reaching. In cases of perennial delays, ship-owners rearrange routes to avoid such ports and only call at key regional hub ports or more efficient neighbouring ports. Evidence shows that ship owners increasingly allocate smaller vessels to the port, partly because of its lack of capacity in handling bigger ones, as well as an unwillingness to subject their larger more productive vessels to costly delays (World Bank 2010). Consequently, the transportation costs are high. In the case of this Port, customer complaints about slow processes continue to characterise customer relations:

${ }^{1}$ The term (I)CFSs is commonly used to refer to a facility affiliated to a parent port or airport where export/import containers are held temporarily in transit and where functions such as container stripping, stuffing and re-packaging may take place. Additional functions may include customs and clearance services. 
Cargo owners would not mind to collect their goods even in 24 hours. Today, the dwell time has deteriorated from 5.3 to 6 days and the shippers pay storage charges to CFS operators for inefficiencies at the facility. (Kenya Shippers Council (KSC) Director)

This has been a perpetual problem of vessel delays for about eight months now. As a result, the production time and deadlines to manufacture garments for export is affected. (Kenya Apparel Manufacturers Association chairman)

In order to address some of these problems, the Port Authority has recently implemented a number of initiatives, focused on streamlining operations and enhancing internal capacity. These include the introduction of a 24-hour work schedule to expedite cargo operations; the consolidation of operations through the implementation of a port-ICT strategy in order to shorten the cargo clearance process, reduce paperwork, and eliminate unnecessary duplication of clearance procedures; and the dredging of the channel to accommodate bigger vessels. Several privately operated ICFSs have also been concessioned and situated close to the port to ease container congestion within the yard. Furthermore, a second container terminal is currently under construction, which is intended to boost handling capacity.

Cumulatively, these changes have translated into a reasonable improvement in the port's performance. For example, between 2008 and 2009, there was a 16.1\% increase in throughput (Ntamutumba 2010). As demonstrated by port throughput statistics (figure 3), there was steady growth in container and conventional cargo throughput between 2000 and the end of the decade.

Figure 3: Trends in total throughput $1982-2011$

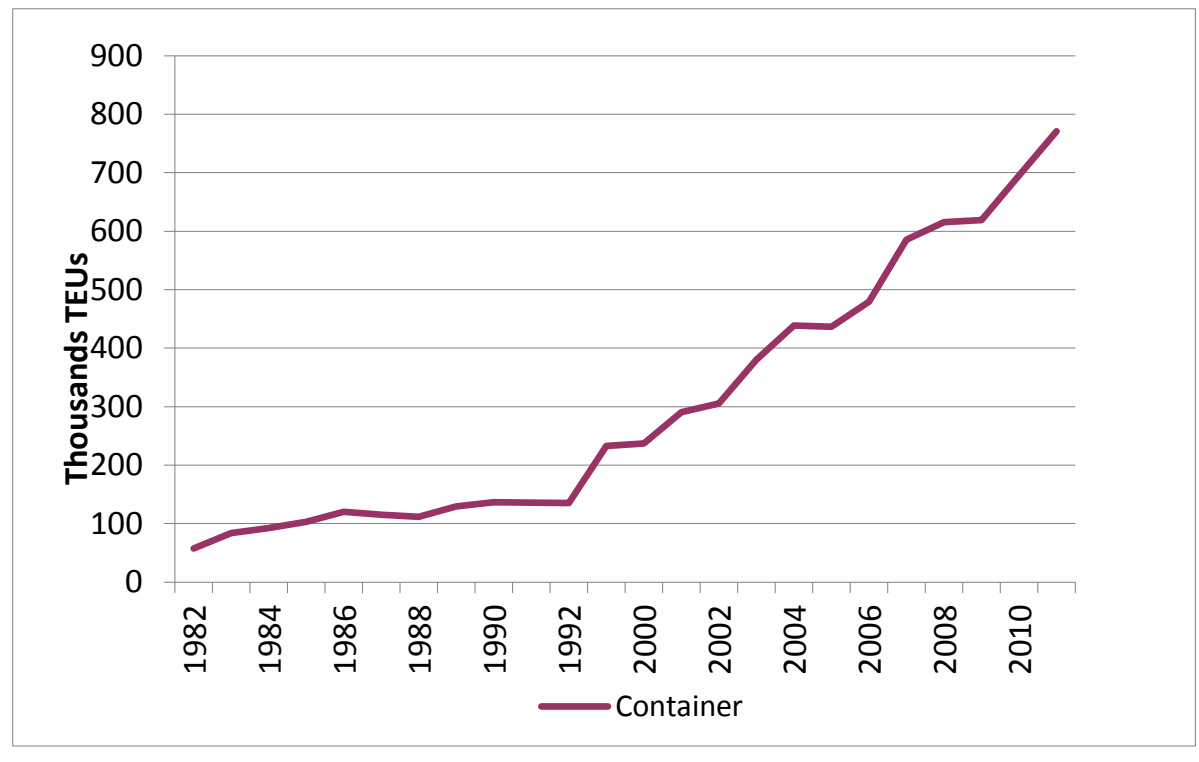

Source: KPA annual statistics, various years

However, a report in the Business Daily magazine on the 7, June 2010 points out that considering its potential capacity, and relative to global performance benchmarks, the port could do much better. The 
key question is why it has failed to rise beyond the status of a second-rate regional feeder port. The issue, as suggested in discussions with port management and key stakeholders, lies more in the wider operations environment, which undermines the outcome of the port's internal efforts. One port management executive summed up the problem thus:

It is very easy to speak about port efficiency and the port has been blamed a lot for all the congestion and other things but one has to realise that we operate in an environment with obstacles beyond our control. KPA has no influence on the state of the roads, the state of the railway... I am afraid that unless things change along the corridor, there will always be problems down here... we aim to be a major regional hub port but it is hard to achieve this under the circumstances.... We are currently just a regional feeder port... (Port Official Jan 2011).

This is because, as a node in a chain of logistics operations, the port relies on downstream/upstream efficiency for its effectiveness. This is captured in the following quote from an interview with a senior port employee:

The work we do here must be viewed alongside what happens elsewhere along the chain. We have implemented a lot of reforms and introduced a lot of changes to make our port more efficient.... But some things we have no control over, they happen elsewhere but affect our work (Port Official Jan 2011).

In this case, the external environment, particularly in terms of inland connectivity and corridor bottlenecks, is highly constraining. It is difficult under such circumstances to achieve effective and sustainable performance improvements.

\section{The ESA corridors: characteristics and weaknesses}

The literature highlights a number of key factors influencing port competitiveness and productivity. These include inter alia, handling capacity and maritime access, technology, skills and know-how, hinterland size and connectivity, trade demand, the quality of supporting industries, corporate strategy and structure and government policies (e.g., Tongzon and Heng 2005; Notteboom et al. 1997; Malchow and Kanafani 2004; Yea et al. 2008). The thesis here is that a port is a complex system where competitiveness is determined by multiple factors related to both internal management systems and the wider external business context. Although the central focus of the discussion is the transportation on the Northern corridor, the analysis is not restricted simply to transport infrastructure constraints. Rather, it includes an examination of the socio-economic and political environment in which the corridor is situated. In addition to the state and capacity of the infrastructure, the ability of the corridor to facilitate efficient transport logistics is affected by safety and security conditions along the transport highways, frontier trade clearance procedures, regional transport policy coordination, as well as regional politics and 
political stability. All these factors influence the performance of key gateway ports. Because of the influence of these broader contexts, the East and Southern African ports have been particularly affected by poor hinterland connectivity and general corridor conditions (AfDB 2010).

In collaboration with the World Bank and the African Development Bank, the continent has recently adopted a corridor management approach to improve accessibility and address these problems (AfDB 2010). In the case of the Eastern and Southern Africa economic region, 11 corridors have been identified, which connect to 8 key ports (see table 2).

Table 2: Eastern and Southern Africa Trade and Transport Corridors

\begin{tabular}{|l|l|l|}
\hline Port & Corridor & Hinterland \\
\hline Djibouti Port & Djibouti-Ethiopia & Djibout; Ethiopia \\
\hline Mombasa & Northern & $\begin{array}{l}\text { Kenya; Uganda; Rwanda; Burundi; } \\
\text { Northern Tanzania; } \\
\text { Southern Ethiopia; Eastern DR-Congo; } \\
\text { South Sudan }\end{array}$ \\
\hline Dar Es Salaam Port & Central & $\begin{array}{l}\text { Tanzania; Burundi; Rwanda; } \\
\text { Democratic Republic of Congo }\end{array}$ \\
\hline Nacala Port & Dar es Salaam & Tanzania; Zambia \\
\hline Beira River Port & Nacala & Mozambique; Zambia; Zimbabwe \\
\hline Pretoria Port & Beira & Mozambique; Zambia \\
\hline Durban & Maputo & Swaziland; South Africa \\
\hline Walvis Bay Port & North-South & $\begin{array}{l}\text { Botswana; Zimbabwe; Zambia; } \\
\text { Malawi; South DRC; Tanzania }\end{array}$ \\
\hline & Trans-Kalahari & South Africa; Namibia \\
\hline & Trans-Kaprivi & Namibia; DRC; Zambia \\
\hline & Trans-Kunene & Namibia; Luanda \\
\hline
\end{tabular}

Source: Compiled from Ntamutumba [8]

Although the corridors are theoretically well defined and mapped out, their effectiveness as avenues of trade and transportation efficiency is yet to be realised. As noted earlier, this is a result of complex issues related to transport infrastructure and the unfavourable geopolitics of the region, leading to a situation where all three possible modes of transportation on the corridors remain inefficient.

The Northern Corridor, which is the focus of this analysis, is a highly limited road network in terms of the condition of its infrastructure (AfDB 2010; Ntamutumba 2010). Unlike more developed regions such as Europe, where transport corridors consist of an effective combination of road, rail and inland waterway transportation, the Northern corridor relies largely on road transportation (Szimba et al. 2004).

Furthermore, the roads have great capacity restrictions, being mainly single lane motorways, as well as lacking basic repair and maintenance for the most part. According to a report in the Business Daily Magazine on the 7, June, 2010, the entire corridor is served by $7,000 \mathrm{~km}$ of road of which only 60 per cent is paved. This means that trucks take a long time to complete runs and require constant, costly repairs because of the strain associated with the poor state of the roads. 
A recent study (Buys et al 2010) concludes that a key reason for the state of the roads in Sub-Sahara Africa is the unwillingness of governments to commit funds to them; they perceive the trade volumes as insufficient to justify the investment. A similar conclusion is made in the 2010 African Development Report (AfDB 2010). It is also suggested that many of the Sub-Saharan African countries are juggling many investment obligations against limited financial resources. Thus, the observation by Briceño et al. (2008) that only aid-dependent countries seem to allocate additional resources to infrastructure is most likely because most foreign aid is targeted and prescriptive. Even where governments commit funds (either out of their budgets or international development grants) to construct roads, maintaining them becomes a problem because of lack of funds and/or poor management Briceño et al. (2008). The consequence is high transportation and trade costs.

The continent has also generally failed to develop, or even maintain, the existing railway infrastructure. The whole continent has a total of $89,000 \mathrm{~km}$ of railroads. These railroads, linking key ports to their hinterlands, often consist of single lines and have little, if any, working interconnections. Furthermore, in only a few cases do they traverse country borders (AfDB 2010), which is similar to the case with roads and is due to the lack of coordinated transport infrastructure development between trading partners along the corridors (AfDB 2010; Buys et al. 2010). This situation is closely mirrored in the Northern Corridor. The corridor railway line, commonly known as the Kenya-Uganda railway, offers little connectivity to the rural production areas and serves little purpose in the way of cross-border intermodal transportation. It consists of only one single railway line of approximately 1,660 km connecting Mombasa port to Kampala and Western Uganda (AfDB 2010). Furthermore, the connection between Uganda and Kenya has been inoperable for most of the past half-century because of lack of funds and, most importantly, the lack of a clear regional policy to coordinate common transport infrastructure development and maintenance. It is because of its network limitation, state of disrepair, and lack of sufficient capacity that most traders prefer to use road transportation.

The potential for an inland trans-border water transport system has also not been exploited, despite the fact that Lake Victoria (the largest freshwater lake in the world) is strategically located to offer a costeffective channel for cross-border transportation between Kenya, Uganda and Tanzania. The lake could also be used as an effective transit mode between ICFSs in Kisumu and neighbouring towns like Mwanza (Tanzania) and Jinja (Uganda). This would enable containers transported by road/rail to ICFSs in Kisumu to proceed by road, rail and lake transportation to the three destinations. Inland waterways have been utilised effectively in other parts of the word to open up economic hinterlands. Europe is one such area where inland waterways serve an effective role in regional intermodal freight transportation (Charler and Ridolfi 1994). Lake Victoria once held similar promise but, as a gradual result of poor regional policy coordination and lack of capital investment, little freight transportation takes place anymore (AfDB 2010). 
All these limitations discussed above mean that the Northern Corridor member states are poorly interconnected with trade transportation regionally and internationally. This situation is reflected in their poor ranking on both the World Bank Logistics Performance Index (LPI) and the UNCTAD Liner Shipping Connectivity Index (LSCI). Out of 155 economies ranked in the WB LPI, Northern Corridor countries have ranked in the bottom 50 consistently between 2007 and 2012. Similarly, out of the 152 economies ranked in UNCTAD LSCI, the key transit countries rank poorly (see table 3).

Table 3: LPI and LSCI ranking of Northern Corridor States

\begin{tabular}{|l|r|r|r|r|}
\hline Country & \multicolumn{1}{l|l|l|l|}{$\begin{array}{l}\text { LPI } \\
\text { 2007 }\end{array}$} & \multicolumn{1}{l|l}{$\begin{array}{l}\text { LPI } \\
\text { 2010 }\end{array}$} & \multicolumn{1}{l|}{$\begin{array}{l}\text { LPI } \\
\text { LSCI, }\end{array}$} & \multicolumn{1}{l|}{$\mathbf{2 0 1 1}$} \\
\hline Kenya & 76 & 99 & 122 & 76 \\
\hline Uganda & 83 & 66 & & \\
\hline Tanzania & 137 & 95 & 88 & 78 \\
\hline Rwanda & 148 & 151 & 139 & \\
\hline Burundi & 113 & & 155 & \\
\hline Ethiopia & 104 & 123 & 141 & \\
\hline Sudan & 64 & 146 & 148 & 88 \\
\hline DRC & & 85 & 143 & 140 \\
\hline
\end{tabular}

Source: World Bank and UNCTAD statistics

A poor ranking on the $\mathrm{LSCl}$ confirms that the region is poorly serviced by shipping lines and, therefore, not adequately connected to the global supply chains. The poor LPI ranking shows a general lack of sufficient internal logistics connectivity. It is important to note that, although LSCI largely applies to countries with a shoreline, poor performance makes an impact on all the landlocked countries that connect to international trade through their ports.

In addition to the infrastructure-related corridor weaknesses, the Northern Corridor is also characterised by a number of more contextual obstacles, which create a highly inefficient logistics environment. First, there are multiple roadblocks at close intervals along the main road that not only cause delays but have also been reported to facilitate crew harassment and extortion from corrupt security officials. A trucking company official described the situation thus:

These roadblocks, they are a big problem... all the way from Mombasa to Congo you are stopped all the time so you stay a long time on the road.... And the police are always asking for kitu kidogo [bribes]... it is a big problem (Trucking Company, December 2010).

The problem of roadblocks, as logistics obstacles, has been highlighted elsewhere (e.g. Buys et al. 2010). Roadblocks are normally erected along the main transit roads, supposedly to maintain highway security and monitor illegal trade activities. They are, more often that not, sources of inefficiency along the corridor. The second major issue relates to safety and security for cargo and transportation crews. Truck drivers operate at all hours of the day and face constant danger from highway robbers, as well as the danger of accidents resulting from the unsafe conditions for large spans of the roads. This situation was described by one truck driver as follows: 
We drive day and night and there is always danger. The roads are full of potholes and trucks roll all the time... it is very dangerous. Sometimes people put obstacles on the road; rocks, logs and even nails... sharp objects to puncture our tires and steal goods. If you resist, you die... (Truck driver Jan 2011)

Another truck driver added:

The road is dangerous.... They are not well marked and too many potholes. They can swallow the whole truck (laughs). Many accidents occur especially if you are driving at night. You have to drive very slowly and that it takes many days... (Truck driver Jan 2011)

The security issue is, however, much more complex. The region has been plagued by political instability for many years, with continuous internal armed struggles and recurrent cross-border insurgencies characterising a big part of the political terrain and making long-distance people and cargo movement risky. More recently, in addition to the overland security problem, the Somali piracy situation in the Gulf of Aden has made the East African coastal waters risky for shipping lines, deterring many ocean carriers from the region's ports.

Another major source of bottlenecks highlighted by stakeholders was the various border crossings. In the case of transit cargoes, a number of frontiers are crossed before they reach their destination within the region. Lack of harmonisation in customs practices at these frontiers, inadequate parking space, outdated IT facilities at the clearance stations, corruption, and general process inefficiencies mean that trucks have to wait for many hours to be cleared. It is reported that trucks spend an average of 18 hours at the Malaba crossing into Uganda from Kenya, and about 12 hours at the Kantune crossing into Rwanda from Uganda (World Bank 2010). This was confirmed in interviews with truck drivers, who explained that they often took up to 72 hours at these crossings. The result is a bunch-up of traffic resulting in costly delays along the logistics chain. During a three-day visit by the research team to the Malaba frontier, the truck queue waiting to be cleared into Uganda from Kenya stretched some two kilometres on all the three days. It was explained that a breakdown in the customs IT system was the cause of the delays. However, as reported in the Daily Nation newspaper on January 10,2012, the queue sometimes stretches 25 kilometres and, according to the truck drivers spoken to during the three days, this was nothing out of the ordinary. A truck company manager explained:

The borders are often chaotic and slow in processing out trucks... so our trucks spend too much time at the border... sometimes a whole 2 days [24 hours]. If you add all the borders that we have to cross in order to get there, you can see the problem (Trucking Company Manager Jan 2011) 
Furthermore, the chaotic nature at these check points has often encouraged corruption because trucking companies wishing to expedite the clearing process often resort to bribing customs officials and police officers who, apparently, can assist a truck in jumping the queue:

Often you have to give 'something' (bribe) if you want to pass quickly. Otherwise, you will be there forever... we all know that; from the police[man] pretending to bring order to the chaos to the customs official at the exit. (Truck driver Jan 2011)

The impact of these obstacles is often analysed from three perspectives: the dollar value losses to businesses and transport companies due to delays, the high risk of loss and damage leading to prohibitive insurance costs, and the overall effect on trade and economic development in the region Limão and Venables 2001). These implications are important for this discussion, but primarily we focus on how these issues transfer to the main regional gateway port and undermine performance despite the best efforts by port management to improve efficiency.

\section{Concluding assessment}

This paper examined the importance of efficient hinterland connectivity for the performance of ports. Inadequate overland transport infrastructure, congested logistics networks, less sophisticated intermodal facilities and prohibitive transportation costs are identified as the major constraints that continue to undermine the effectiveness of the port as a key gateway to the region's international trade. Other constraining contextual factors are identified including roadblocks, inefficient customs clearance procedures at inland frontiers, and the poor state of security in the region. The paper concludes that, in such a situation, any efforts by the Port Authority and management to optimise operations and productivity would be ineffective because the problem lies without the administrative jurisdiction of the port and is one of basic infrastructural incapacity. Thus, recent efforts that include implementing advanced port-ICT, introducing a 24-hour schedule, consolidation of clearance procedures to speed up cargo operations and the concessioning of private ICFSs may not achieve the port's full potential as a key regional trade gateway. For example, shifting port operations from a 12-hour to a 24 -hour schedule within a predominantly eight-hour economy is unlikely to bring sustainable performance improvements. It would only result in the piling of containers in the yard, further choking the system. Similarly, establishing ICFSs just outside the port to alleviate container yard congestion will only achieve short-term relief before cargo cleared from the port piles up in the ICFSs because hinterland cargo off-take remains constrained by upstream logistics bottlenecks.

The performance analysis of the port indicates some improvements in port operations in response to changes in management policies and operations rationalisation. A steady growth in throughput between 2000 and the end of the decade is clearly noticeable. However, this increase is not being supported by a simultaneous enhancement of inland infrastructure capacity, which explains the existing logistical bottlenecks along the corridor and operational inefficiency prevailing within the port precinct. This has 
resulted in slow loading/uploading and handling of cargo/containers that has led to increasing vessel waiting times and poor turnaround rates.

Our qualitative analysis suggests the factors behind the situation may be categorised into three clusters: 1) those directly related to the port's capacity and management, 2) inland corridor mode limitations in terms of carrying capacity, condition of infrastructure and extent of connectivity, and 3) socio-economic problems like security, which create a constrained environment for logistics operations.

Clearly, individual governments have been unable or unwilling to invest in high-capacity ports and sufficient transport infrastructure because of the perceived lack of justifying trade capacity (AfDB 2010; Ntamutumba 2010). In doing so, they fail to realise that under-investment in this sector and, consequently, a costly business environment undermines production capacity and trade, creating a vicious cycle of underdevelopment. A proactive investment approach in transport infrastructure is necessary to open up regional production locations and spur trade capacity. There is no doubt that many private port operators would be hesitant to invest in the region's ports, given the context within which they would have to operate and seek global competitiveness. In the case of Mombasa Port, the prevailing regional political economy and characteristic inland logistics bottlenecks would severely undermine the performance, productivity and return on investment.

Compounding the port management and corridor deficiencies is the complexity of the region's politics and lack of a coordinated policy approach. Such regional policy coordination is essential, not only to keep cross-border trade and transportation channels open, but also to ensure adequate and coordinated infrastructure funding along the entire corridor. It would also ensure effective cross-border transport regulation and the elimination of unnecessary bottlenecks at points such as frontier borders. Effective regional policy coordination is also likely to achieve a more secure transport corridor as a result of member countries adopting joint and coordinated security operations. As noted, the security situation is a major issue affecting both upstream and downstream logistics and undermines trade logistics in the region. As exemplified by the piracy situation, and corroborated by the experiences of inland transport service providers, there are constant security threats to transportation crews, their vessels and cargo.

Enhancing the port's logistical capacity and expanding inland transport infrastructure facilities, combined with the benefits of dedicated transport corridors, will create potential for greater regional economic development. It is imperative, therefore, that all regional governments, industries and the community work out an effective, coordinated approach in planning, designing and developing an effective and internationally competitive integrated port hinterland interface. There are useful lessons to be learnt from the transport integration processes in other regions, and the European Union is a good example. 


\section{References}

African Development Bank (AfDB). 2010. Ports logistics and trade in Africa. New York: Oxford University Press

Amjadi, A. Yates, A. 1995. "Have transport costs contributed to the relative decline of African exports? Some preliminary evidence." World bank working papers. Washington DC.

BITRE. 2009. Australian container ports in an international context. Sessional paper No. 65. Canberra, Australia.

Briceno, C. Smits, K. Foster, V. 2008. Financing public infrastructure in Sub-Saharan Africa: patterns, issues and options. World Bank background paper 15.Washington DC. http://www.eu-africainfrastructure-tf.net/attachments/library/aicd-background-paper-15-fiscal-costs-summary-en.pdf $[15 / 11 / 11]$

Buys, P. Deichmann, U. Wheeler, D. 2010. "Road network upgrading and overland trade expansion in Sub-Saharan Africa." Journal of African Economies 19(3): 399-432.

Charler, J. J. and Ridolfi, G. 1994. "Intermodel transportation in Europe: of Modes, corridors and nodes." Maritime Policy \& Management 21(3): 237-250

Heaver, T. D. 1995. "The implications of increased competition among ports for port policy and management." Port Policy and Management 22: 125 - 133.

Limão, N. Venables, A. J. 2001. "Infrastructure, geographical disadvantage, transport costs and trade." The World Bank Economic Review, 15: 451 - 479.

Malchow, M. B. Kanafani, A. 2004. "A Disaggregate Analysis of Port Selection." Transportation Research 40E: 317 - 337.

Notteboom, T. Coeck, C. Verbeke, A. Winklemans, W. 1997. "Containerisation and the competitive potential of upstream urban ports in Europe." Maritime Policy and Management 24: 285 - 289.

Ntamutumba, C. 2010. Study of the establishment of a permanent regional corridor development working group in PMAESA Region. PMAESA report, Mombasa, Kenya.

Szimba, E. Rothengatter, W. Schoch, M. Guglielminetti, P. 2004. "Evaluation of Transport Infrastructure Projects on Corridors by a Strategic Assessment Framework." Paper presented at the $10^{\text {th }}$ World Conference on Research, Istanbul, Turkey, July $4-8$.

Tongzon, J, Heng, W. 2005. "Port privatisation, efficiency and competitiveness: some empirical evidence from container ports (Terminals)." Transportation Research 39A: 405 - 424. 
UNCTAD. 2003. African Ports: Reform and the Role of the Private Sector. Report by the Secretariat of UNCTAD, (UNCTAD/SDTE/TLB/5)

World bank. 2010. Running on one engine: Kenya's uneven economic performance, with a special focus on the port of Mombasa. Poverty and Economic Management Africa Unit. World Bank, Washington DC. http://siteresources.worldbank.org/KENYAEXTN/Resources/Kenya-Economic-Update-June-2010.pdf [15/11/11] Yea, G. Roe M, Dinwoodie J. 2008. "Evaluating the competitiveness of container ports in Korea and China." Transportation Research 42A: 910 - 921. 